\title{
PERANAN PEER TO PEER LENDING DALAM MENYALURKAN PENDANAAN PADA USAHA KECIL DAN MENENGAH
}

\author{
Serlika Aprita \\ Fakultas Hukum Universitas Muhammadiyah Palembang \\ Jl. Jendral A. Yani. 13 Ulu Palembang 30263 \\ 5312lika@gmail.com
}

\begin{abstract}
The presence of Fintech: Peer to Peer Lending in Indonesia is under the supervision of the Financial Services Authority $(0 \mathrm{~J}) .0 \mathrm{~J}$ is an independent institution that has the authority to regulate and supervise all activities of financial services sector in Indonesia. Through its role, 0J $\mathrm{K}$ has the authority to shut down the Fintech that violates or does not follow the rules which has been set. Particularly the Fintech which gives the negative impact to the development of SMEs. The role of Peer to Peer Lending for SMEs has a positive impact on the economy and industry, especially the growth of the micro industry in some specific regions. The ease of this technology provides as an alternative in funding the industry as it were so unreachable. The type of this research is using the normative one namely legal research which is focusing on examining library materials which are the literatures like books, magazines, and problem related regulations to be as a library research writing.
\end{abstract}

Keywords: Fintech. Peer to Peer Lending, Small Medium Enterprises, , Indonesia Financial Services Authority.

\begin{abstract}
Abstrak
Kehadiran Fintech Peer to Peer Lending di Indonesia, berada dalam pengawasan Otoritas Jasa Keuangan. OJK merupakan lembaga independen yang memiliki otoritas untuk mengatur dan mengawasi seluruh kegiatan dalam sektor jasa keuangan di Indonesia. Melalui perannya itu, maka OJK berwenang untuk menutup Fintech yang melanggar atau tidak mengikuti aturan yang telah ditetapkan. Apalagi jika keberadaan Fintech ini malah memberikan dampak negatif terhadap perkembangan UKM. Jenis penelitian yang digunakan adalah penelitian normatif yaitu penelitian hukum yang dilakukan dengan cara meneliti bahan pustaka yang menggunakan objek kajian penulisan berupa pustaka-pustaka yang ada, baik berupa bukubuku, majalah, dan peraturan-peraturan yang mempunyai korelasi pembahasan masalah, sehingga penulisan ini juga bersifat penulisan pustaka (library research). Peran Peer to Peer Lending bagi UKM memberikan dampak positif terhadap perekonomian dan perindustrian. Terutama pertumbuhan terhadap perindustrian mikro di berbagai daerah. Kemudahan teknologi, memberi pencerahan terhadap kesulitan permodalan dalam kegiatan industri.
\end{abstract}

\section{Kata Kunci: Fintech Peer to Peer Lending UKM OJ K}




\section{PENDAHULUAN}

Era Globalisasi saat ini telah mempengaruhi perekonomian dunia dalam tatanan yang sangat luas, dimana era globalisasi juga mengharuskan ASEAN membuat pembaharuan secara menyeluruh pada kawasan asia tenggara. Hal inilah yang disebut dengan ASEAN VISION 2020. Salah satu unsur pokok dari ASEAN Vision 2020 adalah ASEAN Economic Community atau disebut dengan Masyarakat Ekonomi ASEAN. ${ }^{1}$ Berkaitan dengan hal tersebut diatas diketahui bahwa saat ini finansialadalah salah satu bidang yang mendukung kemajuan perekonomian pada suatu negara.Sektor keuangan memegang peranan yang sangat penting dalam memicu laju pertumbuhan ekonomi dan mempunyai peranan besar dalam perubahan ekonomi secara global. ${ }^{2}$ Dengan demikian semua hal dapat dilakukan menggunakan teknologi tanpa terkecuali. Menurut data yang diambil dari Asosiasi Financial Technology Indonesia (AFTECH), saat ini generasi milennial menjadi pengguna tertinggi metode keuangan modern ini. Teknologi dan internet berperan sangat besar dalam menunjang segala aktivitas kehidupan manusia. Teknologi telah mengajak perdagangan semakin berkembang, membantu pelaku UMKM dalam menjalankan usahanya,mendukung inklusi keuangan negara, dan selalu berinovasi dari tahun ke tahun untuk berkembangnya hal-hal tersebut secara signifikan. ${ }^{3}$

Teknologi menjadikan jangkauan suatu barang maupun jenis layanan data semakin berkembang dan mudah untuk diakses dimanapun oleh setiap orang. Jarak dan waktu bisa ditembus melalui teknologi, Sehingga laju perekonomian juga bisa semakin berkembang dan maju.Penggunaan dan pemanfaatan teknologi digital di Indonesia sangat besar, hal ini tentu saja memberikan dampak bagi beberapa sektor, salah satunya adalah sektor bisnis yang kemudian menghadirkan perdagangan online atau e-commerce. Dampak dari semakin pesatnya perkembangan teknologi dan internet tidak hanya merambah pada industri perdagangan, tetapi juga pada industri keuangan Indonesia. ${ }^{4}$

Finansial teknologi merupakan penggunaan teknologi dalam sistem keuangan yang menghasilkan produk, layanan, teknologi, dan/atau model bisnis baru serta dapatberdampak pada stabilitas moneter, stabilitas sistem keuangan, efesiensi,kelancaran, keamanan dan keandalan sistem pembayaran. Penyelenggaraan teknologi finansial yakni meliputi sistem pembayaran, pendukung pasar,manajemen investasi dan manajemen

\footnotetext{
${ }^{1}$ Budi Nababan. 2014. Pembentukan Peraturan Daerah Tentang Retribusi Perpanjangan Izin Mempekerjakan Tenaga Kerja Asing Sebagai Persiapan Menghadapi Masyarakat Ekonomi ASEAN. hlm.34.

${ }^{2}$ Pramesti Widya Kirana. 2018. Teknologi Finansial dan Masa Depan Pusat Perbankan. Universitas Muhammadiyah Sumatera Utara.hlm.1.

${ }^{3}$ Song Yee leng. 2018. Financial Technologies : A Note on Mobile Payment, Jurnal dan Perbankan. No. 2. hlm 51-62.

${ }^{4}$ Ernama, Budiharto dan Hendro S. 2017. Pengawasan Otoritas Jasa Keuangan Terhadap Financial Technology. Diponegoro Law Journal. No.3. hlm 1-2.
} 
resiko, pinjaman, pembiayaan, penyediaan modal, dan jasa finansial lainnya, hal ini berdasarkan isi dari Peraturan Bank Indonesia Nomor19/12/PBI/2017. ${ }^{5}$

Layanan pinjam meminjam uang berbasis teknologi sudah diatur dalam Peraturan Otoritas Jasa Keuangan (OJK) No.77/2016 tentang pinjam meminjam uang berbasis teknologi, sejak aturan itu terbit pada 28 Desember 2016 jumlah perusahaan P2P Lending kian bertambah. perkembangan fintech P2P lending sepanjang beberapa tahun lalusangat signifikan, peminat dan pengguna jasa baik dari pemberi pinjaman maupun pencari pinjaman sangat besar. ${ }^{6}$

Fintech peer-to-peer lending merupakan alternatif potensial sumber pembiayaan bagi masyarakat terutama untuk pembiayaan bagi usaha mikro, kecil, dan menengah (UMKM). Dalam pelaksanaan operasionalnya, sistem dalam fintech peer-to-peer lending sangat mudah untuk dijangkau maupun diakses baik oleh pemberi pinjaman maupun penerima pinjaman.

Layanan keuangan digital atau financial technologydilaksanakan dengan berlandaskan aturan hukum. Hal ini berdasarkan dengan dikeluarkannyaPeraturan Otoritas Jasa Keuangan Nomor 77/POJK.01/2016 tentang layanan pinjam meminjam uang berbasis teknologi informasi menjelaskan bahwa layanan pinjam meminjam uang berbasis teknologi informasi adalah penyelenggara layanan jasa keuangan untuk mempertemukan pemberi pinjaman dengen penerima pinjaman dalam rangka melakukan perjanjian pinjam meminjam dalam mata uang rupiah secara langsung melalui sistem elektronik dengan menggunakan jaringan internet.Fintech peer-to-peer lending tergolong aktivitas pembaruan proses bisnis, model bisnis, dan instrument keuangan yang memberikan nilai tambah baru di sektor jasa keuangan dengan melibatkan kemajuan digital saat ini yang dikenal dengan istilah inovasi keuangan digital (IKD). ${ }^{7}$

Otoritas Jasa Keuangan juga menangkap peran fintechuntuk Indonesia yaitu untuk mendorong pemerataan tingkat kesejahteraan penduduk, membantu pemenuhan kebutuhan pembiayaan dalam negeri yang masih sangat besar, mendorong distribusi pembiayaan nasional yang masih belum merata, meningkatkan inklusi keuangan serta mendorong kemampuan ekspor UMKM yang saat ini masih rendah dan juga agar para pelaku UMKM di Indonesia tidak lagi hanya semata-mata mengandalkan pinjaman bank untuk mendapatkan modal usaha karena seperti yang kita ketahui bahwa pinjaman bank

\footnotetext{
${ }^{5}$ Heri Setiawan, Mutiara Girindra, dan Octavianna Evangelista. 2017. Aspek hukum finansial teknologi di indonesia: regulasi startup fintech oleh bank indoneisa dalam pelarangan perkembangan penggunaan bitcoin di indonesia. hlm.1.

${ }^{6}$ Dhiya Tsuroyya dan Muzayyanah. 2019. Analisis Pelaksanaan Musyarakah Pada Layanan Financial Technology Peer To Peer Lending Syariah Di Indonesia (Studi Pt Syarfi TeknologiFinansial) No.2. hlm 34-35.

${ }^{7}$ Jadzil Baihaqi. 2018. Financial Technology Peer-To-Peer Lending Berbasis Syariah di Indonesia. Journal of Sharia Economic Law. Institut Agama Islam Negeri Kudus. No.2. hlm. 119-120.
} 
biasanya memiliki bunga yang cukup tinggi, belum lagi prosedur dan persyaratan yang umumnya cukup sulit. ${ }^{8}$

Financial technology peer-to-peer lending merupakan salah satu bentuk inovasi teknologi di bidang layanan jasa keuangan khususnya pinjaman/pembiayaan/pendanaan yang menghilangkan hambatan-hambatan yang sering dialami masyarakat. Saat ini dengan hadirnya fintech ini masyarakat dapat dengan mudah mengakses pinjaman/pembiayaan untuk meningkatkan usaha yang dimiliki atau kebutuhan seharihari yang harus dipenuhi. ${ }^{9}$ Bukan hanya untuk mendapatkan keuntungan atau pendapatan yang besar bagi perusahaan startup namun, keberadaan fintech juga ternyata bisa meningkatkan taraf hidup serta daya beli masyarakat banyak. ${ }^{10}$

Pandemi yang sedang terjadi di seluruh dunia ini telah membuat banyak negara memberlakukan pembatasan bahkan lockdown, melayangkan pukulan telak kepada perekonomian terlebih kepada sektor UMKM. Keengganan masyarakat untuk keluar rumah dan membelanjakan uangnya bisa jadi penyebab turunnya pendapatan dan bahkan mengancam keberlangsungan bisnis mereka. Hal ini sangat disayangkan karena UMKM berpotensi mendongkrak pemulihan ekonomi nasional di mana 64 juta unit UMKM telah menopang perekonomian Indonesia selama ini, berkontribusi $97 \%$ terhadap total tenaga kerja dan 60\% dari Produk Domestik Bruto (PDB) nasional. ${ }^{11}$

Permodalan dan arus kas selalu memegang peran penting bagi pertumbuhan dan keberlangsungan bisnis. Terlebih di tengah pandemi, keberadaan modal menjadi seperti 'penyambung napas' bagi para pelaku bisnis. Bagaimana tidak, sekarang ini pergerakan arus kas UMKM melambat baik dari segi produksi, distribusi, serta penjualan. Di satu sisi ada pemerintah dan berbagai pihak telah berupaya menggenjot daya beli dan budaya belanja masyarakat di tengah pandemi. Tentu di sisi lain perlu ada pihak yang membantu UMKM mendapatkan modal untuk menjaga kapasitas produksinya. Mengambil peran krusial, fintech lending membukakan akses permodalan yang lebih luas dan terjangkau. Memang benar adanya, fintech lending menyediakan pembiayaan yang lebih cepat, mudah, terlebih lagi tanpa jaminan yang signifikan seperti di bank atau lembaga keuangan lainnya. Pelaku UMKM jadi bisa memanfaatkan modal dengan segera untuk mempertahankan bisnisnya di tengah krisis.

Kontribusi sektor Usaha Mikro, Kecil dan Menengah (UMKM) terhadap produk domestik bruto semakin menggeliat dalam lima tahun terakhir. UMKM di Indonesia saat

\footnotetext{
${ }^{8}$ Suharyati dan Pahrizal Sofyan.2018. Edukasi Fintech Bagi Masyarakat Desa Bojong Sempu Bogor. Jurnal Bakti Masyarakat Indonesia. Jakarta: Universitas Pembangunan Nasional Veteran. No. 2. hlm 5.

${ }^{9}$ Jadzil Baihaqi. Op. Cit. hlm. 121.

${ }^{10}$ Kornelius Benuf. 2020. Urgensi Kebijakan Perlindungan Hukum Terhadap Konsumen Fintech Peer To Peer Lending Akibat Penyebaran Covid-19. Jurnal Rechts Vinding: Media Pembinaan Hukum Nasional, Vol.9 No. 2, hlm. 203-217

${ }^{11}$ G.M.Fitriyadi. 2019. Analisis mitigasi resiko financial technology peer to peer $(P 2 P)$ lending dalam penyaluran pembiayaan terhadap UMKM di Indonesia (Studi kasus PT. Ammana Fintek Syariah). Jurnal Ekonomi Dan Bisnis, 7(2), hlm.2- 13.
} 
ini dinilai berperan penting dalam pertumbuhan pembangunan dan ekonomi.Di antara UMKM, industri ekonomi kreatif juga tercata berkontribusi positif dengan pertumbuhan $5,6 \%$ sejak tahun 2010. Sumbangannya terhadap produk domestik bruto (PDB) mencapai $7,1 \%$. Untuk hal ini, pemerintah menargetkan kontribusi PDB mencapai $7-7,5 \%$ hingga tahun 2019. Dengan melihat fakta yang ada, tentunya adalah tugas masyarakat untuk terus mendorong kemajuan produktivitas para UMKM di masa depan. Akan tetapi, saat ini sejumlah besar UMKM di Indonesia masih menghadapi masalah besar, berupa terbatasnya modal usaha.

Merujuk pada uraian di atas secara keseluruhan maka dapat ditarik beberapa rumusan masalah yaitu: 1). Bagaimanakah pengaturan hukum tentang Peer to Peer Lending? Dan 2). Bagaimanakah peran Peer to Peer Lending untuk menyalurkan pendanaan pada Usaha Kecil dan Menengah?

\section{METODE PENELITIAN}

Jenis penelitian yang digunakan adalah penelitian normatif yaitu penelitian hukum yang dilakukan dengan cara meneliti bahan pustaka yang menggunakan objek kajian penulisan berupa pustaka-pustaka yang ada, baik berupa buku-buku, majalah, dan peraturan-peraturan yang mempunyai korelasi pembahasan masalah, sehingga penulisan ini juga bersifat penulisan pustaka (library research).

\section{PEMBAHASAN}

\section{A. Aturan Hukum Peer to Peer Lending}

Perkembangan informasi diciptakan seiring dengan kebutuhan manusia dan teknologi informasi telah mengubah cara bertransaksi serta membuka peluangpeluang baru dalam transaksi bisnis. ${ }^{12}$ Salah satu bentuk bisnis dari perkembangan informasi tersebut ialah financial technology (fintech), yang merupakan penggunaan teknologi untuk memberikan kemudahan dan solusi dalam bidang finansial. ${ }^{13}$ Kehadiran Fintech merupakan jawaban bagi masyarakat yang belum tersentuh dengan layanan jasa perbankan sehingga mendatangkan kemudahan bagi setiap lapisan masyarakat untuk mendapatkan layanan jasa keuangan yang praktis dan cepat. $^{14}$

Fintech berpusat pada perusahaan yang melakukan inovasi di bidang jasa keuangan dengan sentuhan teknologi modern. Fintech P2P lending merupakan

\footnotetext{
${ }^{12}$ Haris Faulidi Asnawi.2004. Transaksi Bisnis E-Commerce Perspektif Islam. Yogyakarta: Magistra Insania Press. hlm.42.

${ }^{13}$ Kornelius Benuf, Ery Agus Priyono, Siti Mahmudah, Siti Malikhatun Badriyah, Bagus Rahmanda, A. S. 2020. Efektifitas Pengaturan dan Pengawasan Bisnis Financial Technology (Peer to Peer Lending) di Indonesia. Pandecta: Jurnal Penelitian Ilmu Hukum (Research Law Journal), Vol.15 No.2, hlm. 210-230.

${ }^{14}$ Adi Setiadi Saputra, Perlindungan Terhadap Pemberi Pinjaman Selaku Konsumen dan Tanggungjawab Peer to Peer Lending di Indonesia, Vol.5. No.1: Veritas Et Justitia,hlm.258.
} 
Volume 16, Nomor 1, Januari - Juni 2021

bentuk fintech yang diminati oleh masyarakat di Indonesia. P2P lending adalah sebuah platform teknologi yang mempertemukan secara digital peminjam (UKM) yang membutuhkan modal usaha dengan pemberi pinjaman yang mengharapkan return yang kompetitif. ${ }^{15}$

Pesatnya perkembangan Fintech tidak hanya membawa dampak positif saja, akan tetapi banyak permasalahan-permasalahan yang muncul, salah satunya ialah dari layanan pinjaman uang berbasis Fintech atau Peer To Peer Lending (P2PL). Mudahnya syarat dalam pengajuan pinjaman membuat banyak orang tergiur untuk mengajukan pinjaman, dimana syaratnya hanya bermodalkan foto KTP dan mengisi data pribadi saja. setiap orang dapat dengan mudah mendapatkan dana pinjaman secara cepat, namun dari kemudahan tersebut debitur dapat terjebak dalam jerat bunga pinjaman yang tinggi, hal ini disebabkan belum adanya aturan mengenai batas atas bunga yang ditetapkan terhadap layanan ini, serta terjadinya tindakan penagihan pinjaman yang dilakukan secara intimidatif dimana hal ini menimbulkan keresahan di masyarakat. ${ }^{16}$ Banyaknya pengaduan terkait tindakan intimidasi dan teror yang dialami debitur pada proses penagihan pinjaman oleh perusahaan penyelenggara Fintech P2P lending kini menjadi sorotan publik dan menuai persoalan serius yang harus segera ditangani. ${ }^{17}$

Adapun penegakan hukum terhadap debitur pada layanan Peer to Peer Lending diatur di dalam beberapa Undang-Undang dan Peraturan yang mengaturnya, yaitu sebagai berikut :

\section{Peraturan Otoritas Jasa Keuangan (POJK) Nomor 77/POJK.01/2016}

Berkembangnya perusahaan fintech $P 2 P$ lending sebagai penyedia jasa keuangan berbasis teknologi informasi mendorong Otoritas Jasa Keuangan (OJK) selaku regulator dan pengawas kegiatan di sektor jasa keuangan untuk membentuk Peraturan Otoritas Jasa Keuangan (POJK) Nomor 77/POJK.01/2016 Tentang Layanan Pinjam Meminjam Uang Berbasis Teknologi Informasi.

Dalam POJK.01/77/2016 menyebutkan bahwa "layanan pinjam meminjam berbasis teknologi informasi didefinisikan sebagai penyelenggaraan layanan jasa keuangan untuk mempertemukan pemberi pinjaman dengan penerima pinjaman dalam rangka melakukan perjanjian meminjam dalam mata uang rupiah secara langsung melalui sistem elektronik dengan menggunakan jaringan internet." POJK merupakan aturan khusus yang mengatur dan mewajibkan perusahaan fintech

\footnotetext{
${ }^{15}$ Reynold Wijaya. P2P Lending: Wujud Baru Inklusi Keuangan. diakses tanggal 14 Desember 2020.

${ }^{16}$ Fry Anditya Rahayu Putri Rusadi, Kornelius Benuf, 2020, Fintech peer to peer lending as a financing alternative for the development MSMEs in Indonesia, Legallity:Jurnal Ilmiah Hukum, Vol. 8 No.2.hlm. 233.

${ }^{17}$ Wahid Wachyu Adi Winarto. 2020. Peran Fintech dalam Usaha Mikro Kecil dan Menengah (UMKM). Jurnal Ekonomi \& Ekonomi Syariah, 3(1), hlm.61.
} 
Volume 16, Nomor 1, Januari - Juni 2021

$P 2 P$ lending untuk mendaftar kepada OJK agar memiliki izin beroperasi sesuai dengan ketentuan Pasal 77 POJK tersebut. Akan tetapi, keberadaan perusahaan fintech $P 2 P$ lending ini menimbulkan berbagai permasalahan dalam menjalankan kegiatan usahanya di masyarakat. Salah satunya ialah keberadaan perusahaan fintech $P 2 P$ lending ilegal yang berjumlah cukup banyak. ${ }^{18}$

Mayoritas perusahaan fintech $P 2 P$ lending ilegal tersebut seringkali melakukan penagihan utang dengan cara intimidasi dan melanggar hak privasi dari debitur. Contohnya seperti ketika hutang debitur jatuh tempo, perusahaan tersebut melakukan penagihan dengan cara mengancam akan menyebarkan data pribadi konsumen di media sosial, melakukan intimidasi serta pengancaman kepada keselamatan konsumen. ${ }^{19}$ Tidak hanya pihak debitur saja yang diancam tetapi juga kepada teman, hingga keluarga nasabah yang juga dianggap sebagai penanggung jawab pembayar hutang debitur diperusahaan tersebut. ${ }^{20}$

\section{Pasal 39 Peraturan Otoritas Jasa Keuangan (POJK) Nomor 77/POJK.01/2016}

Permasalahan yang dialami debitur tidak hanya dilakukan oleh perusahaan fintech P2P lending ilegal saja, tetapi juga perusahaan yang telah terdaftar dan memiliki izin beroperasi dari OJK. Salah satu contoh platform fintech yang bermasalah tersebut ialah RupiahPlus, yang diluncurkan oleh PT Digital Synergy Technology. Seseorang bernama Ali Akbar terkejut ketika mendapat pesan dengan kata kasar dan menyiratkan ancaman pada aplikasi WhatsAppdan meminta untuk menyampaikan pesan kepada teman bernama Satria agar melunasi utang yang dipinjam dari platform RupiahPlus. Sesuai dengan Pasal 39 POJK Nomor 77/POJK.01/2016 Tentang Layanan Pinjam Meminjam Uang Berbasis Teknologi Informasi menyebutkan bahwa "Pelaku Usaha Jasa Keuangan dilarang dengan cara apapun, memberikan data dan/atau informasi mengenai Konsumen nya kepada pihak ketiga“.

Lembaga Bantuan Hukum (LBH) menghimpun laporan dan pengaduan dari korban fintech $P 2 P$ Lending yang dirugikan dengan kasus dugaan pelanggaran hukum dan pelanggaran hak asasi manusia. LBH Jakarta juga mendapatkan laporan masyarakat bahwa perusahaan fintech P2P lending yang sudah terdaftar di OJK pun merugikan masyarakat. Berdasarkan pengaduan yang diterima oleh LBH Jakarta, 25 dari 89 penyelenggara aplikasi pinjaman online yang dilaporkan kepada LBH Jakarta merupakan penyelenggara aplikasi yang terdaftar di OJK. Hal ini menunjukan bahwa terdaftarnya penyelenggara aplikasi pinjaman online di OJK, tidak menjamin

\footnotetext{
${ }^{18}$ Raka Fauzan Hatamia, Elisatris Gultomb, Anita Afriana. 2019. Penegakan Hukum Terhadap Perusahaan Financial technology P2p Lending Dalam Kegiatan Penagihan Pinjaman Uang Yang Melanggar Asas Perlindungan Konsumen Dikaitkan Dengan Hukum Perlindungan Konsumen. Jurnal Ilmu Hukum Kenotariatan. Bandung: Universitas Padjadjaran. hlm. 158.

${ }^{19}$ Haris Prabowo. https://tirto.id/cerita-orang-pinjam-uang-yang-diteror-perusahaan-fintech-c9cU. diakses tanggal 14 Desember 2020.

${ }^{20} \mathrm{Ibid}$. Haris Prabowo.
} 
minimnya terjadinya pelanggaran di industri bisnis model ini.Khusus bagi perusahaan fintech $P 2 P$ lending ilegal, OJK tidak tinggal diam menghadapi permasalahan ini. Melalui Satgas Waspada Investasi OJK yang bekerjasama dengan Kementerian Komunikasi dan Informatika telah melakukan pemblokiran terhadap layanan fintech P2P lending ilegal yang masih beredar di Indonesia.

\section{Pasal 47 Peraturan Otoritas Jasa Keuangan (POJK)}

Bagi fintech P2P lending yang sudah terdaftar, OJK memberikan sanksi administratif sesuai dengan Pasal 47 POJK tentang Layanan Pinjam Meminjam Uang Berbasis Teknologi Informasi.

Pasal 47 PJOK menyebutkan bahwa :

a. Atas pelanggaran kewajiban dan larangan dalam peraturan OJK ini, OJK berwenang mengenakan sanksi administratif terhadap Penyelenggara berupa:

i. peringatan tertulis;

ii.benda, yaitu kewajiban untuk membayar sejumlah uang tertentu;

iii.pembatasan kegiatan usaha; dan

iv.pencabutan izin

b. Sanksi administratif sebagaimana dimaksud pada ayat (1) huruf bsampai denganhuruf $\mathrm{d}$, dapat dikenakan dengan atau tanpa didahului pengenaan sanksi administratif berupa peringatan tertulis sebagaimana dimaksud pada ayat (1) huruf a.

c. Sanksi administratif berupa denda sebagaimana dimaksud pada ayat (1) huruf b dapat dikenakan secara tersendiri atau secara bersama-sama dengan pengenaan sanksi administratif sebagaimana dimaksud pada ayat (1) huruf c dan huruf $d$.

Namun, salah satu tindakan seperti pemblokiran tersebut dianggap tidak maksimal karena perusahaan fintech $P 2 P$ lending ilegal tetap berjumlah banyak dan memberikan penawaran pinjaman uang kepada masyarakat, baik di aplikasi yang terdapat di Google Play Store, website, maupun SMS. Artinya walaupun perusahaan tersebut telah diblokir akan muncul lagi perusahaan fintech $P 2 P$ lending ilegal dengan jumlah lebih banyak. ${ }^{21}$

OJK mengatakan bahwa pengawasan yang dilakukan terbatas hanya pada perusahaan fintech $P 2 P$ lending yang terdaftar saja, tidak perusahaan yang ilegal.Ketentuan sanksi dalam POJK tersebut dianggap belum maksimal karena baru sebatas administrasi berupa pencabutan izin. Bareskrim Polri sebagai aparat penegak hukum mengalami kendala dalam melakukan penegakan hukum, terutama mengenai posisi server dari perusahaan fintech $P 2 P$ lending. perusahaan fintech $P 2 P$ lending

${ }^{21}$ Op Cit. hlm.159. 
Volume 16, Nomor 1, Januari - Juni 2021

ilegal yang beroperasi di Indonesia memiliki server di luar negeri karena posisi server yang berada di luar jangkauan hukum Indonesia inilah yang menjadi hambatan dalam proses penyidikan.Dapat dikatakan bahwa tindakan penegakan hukum terhadap perusahaan fintech P2P lending belum menciptakan perlindungan, ketertiban dan kepastian hukum bagi konsumen.

Permasalahan penegakan hukum terhadap perusahaan fintech $P 2 P$ lending harus sesuai dengan ketentuan-ketentuan hukum yang berlaku di sektor jasa keuangan dan bagaimana konsep penegakan hukum dalam meminimalkan kegiatan perusahaan fintech P2P lending yang merugikan debitur sehingga hak-hak debitur dapat terlindungi. ${ }^{22}$

Penegakan hukum adalah upaya untuk mewujudkan pencapaian tujuan hukum dalam mendukung keberhasilan penegakan hukum itu sendiri, maka hal-hal seperti ketersediaan perangkat hukum, lembaga-lembaga hukum, dan aparat penegak hukum yang semuanya dijamin memadai dan berkualitas baik. ${ }^{23}$ Fungsi hukum sebagai sarana pembangunan di bidang ekonomi memegang peranan penting dalam kemajuan perekonomian suatu bangsa. ${ }^{24}$

Implementasi dari hukum tersebut tercermin dalam kegiatan penegakan hukum sebagai salah satu instrumen penting dalam pembangunan ekonomi di masyarakat. Penegakan hukum berkaitan dengan 3 (tiga) unsur sebagaimana yang dikemukakan oleh Radbruch, yaitu keadilan, kepastian, dan kemanfaatan yang mesti dipadukan secara seimbang. ${ }^{25}$

Pelaksanaan Penegakan Hukum dipengaruhi oleh

a. Faktor Hukumbeberapa Faktor sebagai berikut: ${ }^{26}$

b. Faktor Penegakan Hukum, yaitu pihak-pihak yang membentuk maupun yang menerapkan hukum

c. Faktor Sarana atau Fasilitas yang mendukung penegakan hukum

d. Faktor Masyarakat, yakni lingkungan dimana hukum tersebut berlaku atau diterapkan

e. Faktor Kebudayaan, yakni sebagai hasil karya, cipta, dan rasa yang didasarkan pada manusia di dalam pergaulan hidup.

${ }^{22} O p$. Cit. Raka Fauzan Hatamia, Elisatris Gultomb, Anita Afriana.

${ }^{23}$ Janus Sidabalok. 2012.Hukum Perusahaan: Analisis Terhadap Pengaturan Peran Perusahaan Dalam Pembangunan Ekonomi Nasional Di Indonesia. Bandung: Nuansa Aulia. hlm. 32.

${ }^{24}$ Mochtar Kusumaatmadja. 1986.Pembinaan Hukum Dalam Rangka Pembangunan Nasional. Bandung: Binacipta. hlm. 11.

${ }^{25} \mathrm{Op}$ Cit. hlm.32.

${ }^{26}$ Soerjono Soekanto. 1983. Faktor-Faktor Yang Mempengaruhi Penegakan Hukum. Jakarta: Rajawali Press. hlm 8. 
Volume 16, Nomor 1, Januari - Juni 2021

Penegakan hukum juga memegang peranan penting dalam bidang ekonomi. Hal tersebut menjadi penting untuk melindungi kepentingan ekonomis dari semua pihak yang terkait di dalamnya, bahkan berkaitan dengan keberhasilan pembangunan ekonomi.Salah satu upaya melindungi kepentingan ekonomis tersebut ialah dengan memberikan perlindungan bagi debitur (konsumen) dalam mengakses layanan jasa keuangan yang disediakan oleh perusahaan fintech P2P lending. ${ }^{27}$

\section{Pasal 31 ayat (1) pojk nomor 1/pojk.07/2013}

Pasal 31 ayat (1) POJK Nomor 1/POJK.07/2013 tentang Perlindungan Konsumen Sektor Jasa Keuangan menyebutkan bahwa "Pelaku Usaha Jasa Keuangan dilarang dengan cara apapun, memberikan data dan/atau informasi mengenai Konsumen nya kepada pihak ketiga."

Perusahaan-perusahaan fintech $P 2 P$ lending selaku penyelenggara Fintech P2P Lending tidak diperkenankan memberikan data atau informasi mengenai nasabah ke pihak ketiga, kecuali atas persetujuan nasabah.Isi yang sama juga diatur dalam Pasal 39 POJK Nomor 77/POJK.01/2016 Tentang Layanan Pinjam Meminjam Uang Berbasis Teknologi Informasi. Artinya, kerahasiaan data debitur menjadi aspek penting dalam perlindungan debitur di sektor jasa keuangan. Namun fakta-fakta di masyarakat malah sebaliknya. Data-data pribadi dari konsumen disebarkan luaskan oleh perusahaan-perusahaan fintech P2P lending tersebut tanpa seizin dari debiturdikarenakan terlambatnya membayar hutang pinjaman kepada pihak kreditur atau pihak debitur yang memang tidak ingin membayar hutangnya. OJK selaku regulator dan pengawas di sektor jasa keuangan tentunya harus mampu melindungi kepentingan konsumen yang dirugikan. ${ }^{28}$

\section{Pasal 9 Huruf C Undang-undang Nomor 21 Tahun 2011 tentang Otoritas Jasa Keuangan (OJK)}

Keberadaan perusahaan-perusahaan fintech $P 2 P$ lending ilegal pada faktanya meresahkan konsumen, namun perusahaan fintech $P 2 P$ lending yang terdaftar pun memiliki permasalahan yang sama. Mengacu pada ketentuan Pasal 9 huruf C Undang-Undang Nomor 21 Tahun 2011 tentang OJK yang berisi tentang kewenangan OJK untuk melakukan pengawasan, pemeriksaan, penyidikan, perlindungan konsumen, dan tindakan lain terhadap lembaga jasa keuangan, pelaku, dan/atau penunjang kegiatan jasa keuangan, OJK melalui satgas waspada investasi seharusnya mampu untuk melakukan tindakan penegakan hukum bukan hanya kepada perusahaan-perusahaan fintech P2P lending yang terdaftar saja, melainkan juga yang ilegal.

${ }^{27}$ Ibid. hlm.8.

${ }^{28}$ Alfian Putra Abdi. Memperkarakan Fintech P2P Lending Bermasalah. https://tirto.id/memperkarakan-fintech-p2p-lending-bermasalah-db3F. diakses tanggal 14 Desember 2020. 
Volume 16, Nomor 1, Januari - Juni 2021

Regulasi hukum seperti POJK membuat penegakan hukum terhadap perusahaan-perusahaan fintech $P 2 P$ lending menjadi terbatas, khususnya bagi perusahaan fintech $P 2 P$ lending yang ilegal. OJK pun mengakui bahwa penegakan hukum terhadap perusahaan-perusahaan fintech $P 2 P$ lending, khususnya yang ilegal disebabkan karena peraturan masih sebatas POJK sehingga sanksi hanya sebatas administrasi berupa pencabutan izin. Hal ini berbeda dengan sektor jasa finansial lain seperti perbankan, asuransi, hingga pasar modal yang penegakan hukumnya lebih mudah lantaran memiliki payung hukum selevel undang-undang. ${ }^{29}$

Dengan belum adanya regulasi hukum yang tepat dan mumpuni untuk melindungi kepentingan konsumen di sektor jasa keuangan, dapat dikatakan bahwa faktor hukum atau faktor peraturannya sendiri yang menjadi salah satu faktor yang mempengaruhi belum berjalannya tindakan penegakan hukum yang baik dalam permasalahan perusahaan fintech $P 2 P$ lending dalam penagihan pinjaman uang yang merugikan konsumen. Kedua, ialah faktor penegak hukum nya sendiri. Terhambatnya penegakan hukum karena posisi server yang berada di luar jangkauan hukum Indonesia dan menjadi hambatan pada proses penyidikan dikarenakan belum adanya peraturan hukum setingkat perundang-undangan yang sedemikian lengkapnya sehingga dapat mendorong dan mengatur bagaimana seharusnya penegakan hukum tersebut dilaksanakan.

Apabila peraturan perundang-undangan sudah baik tetapi mental penegak hukumnya kurang baik, maka akan terjadi gangguan pada sistem penegakan hukum, begitu juga sebaliknya. Ketiga ialah faktor masyarakatnya sendiri. Dengan semakin banyaknya perusahaan fintech P2P lending, khususnya yang illegal, seharusnya masyarakat mampu secara cermat dan selektif dalam memilih platformplatform pinjaman uang secara online mana yang tepat dan tidak merugikanpada layanan P2P lending yang disediakan perusahaan fintech. Faktanya, masih banyak masyarakat yang belum memahami risiko dari melakukan transaksi pinjaman uang secara online, terutama yang disediakan oleh perusahaan fintech $P 2 P$ lending ilegal. pemahaman-pemahaman kepada masyarakat tersebut seharusnya juga diikuti dengan adanya peraturan hukum yang mampu mengakomodir dan melindungi kepentingan masyarakat.

Keberadaan suatu peraturan seperti undang-undang sangat diperlukan di industri fintech karena keberadaannya penting dan dapat memberikan pengaruh yang besar untuk terwujudnya penegakan hukum bagi semua masyarakat pengguna berbagai layanan pada perusahaan fintech khususnya $P 2 P$ lending. ${ }^{30}$

\section{Pasal 28 G ayat (1) UUD 1945 tentang Menjamin Hak Privasi Dari Warga Negara}

\footnotetext{
${ }^{29}$ Vincent Fabian Thomas. OJK Akui Terhambat Payung Hukum Soal Penanganan P2P Lending Ilegal.https://tirto.id/ojk-akui-terhambat-payung-hukum-soal-penanganan-p2p-lending-ilegaldiUu.. diakses tanggal 14 Desember 2020.

${ }^{30}$ Op.cit. hlm. 165 .
} 
Data-data pribadi yang disebarkan secara luas melalui media sosial maupun media lainnya tentu melanggar hak-hak privasi yang dimiliki oleh konsumen dan tidak sesuai dengan asas keamanan dan keselamatan konsumen. Padahal, UUD 1945 menjamin hak privasi dari warga negara sebagaimana yang disebutkan dalam Pasal 28 G ayat (1) UUD 1945. Pasal tersebut menyebutkan bahwa setiap orang memiliki hak atas perlindungan diri pribadi atas tindakan atau perbuatan yang dilakukan. Menjadi kewajiban pemerintah dalam rangka pelayanan penyelenggaraan negara agar warga negara mendapatkan perlindungan serta keamanan terkait dengan hak asasi manusia, salah satunya berkaitan dengan hak privasi. Hal tersebut tentu saja mencakup hak konsumen dalam melakukan berbagai keperluannya dengan perusahaan-perusahaan fintech salah satunya $\mathrm{P} 2 \mathrm{P}$ lending.

P2P lending pada sektor jasa keuangan harus dijamin oleh perusahaanperusahaan untuk tidak akan menyebarkan data-data para konsumen tanpa seizin dari konsumen yang bersangkutan. ${ }^{31}$ Masyarakat selaku konsumen tentunya memiliki hak-hak yang wajib dipatuhi dan dijamin oleh pelaku usaha, dalam hal ini perusahaan-perusahaan fintech $\mathrm{P} 2 \mathrm{P}$ lendingmaupun Pemerintah selaku penyelenggara negara dalam perlindungan terhadap data-data pribadi agar tidak disalahgunakan dan disebarkan secara luas. Suatu peraturan hukum yang dibentuk dalam implementasi tindakan penegakan hukum agar terlaksana dengan efektif di masyarakat tentunya harus memperhatikan keserasian-keserasian di atas sehingga dibutuhkan koordinasi antar instansi terkait agar tindakan penegakan hukum dapat berjalan dengan baik dan sebagaimana mestinya. ${ }^{32}$

\section{Peraturan Pemerintah Nomor 53 Tahun 2017}

Kesulitan yang dihadapi oleh OJK melalui Satgas Waspada Investasi dan Bareskrim Polri dalam tindakan penagihan pinjaman uang yang merugikan konsumen ialah berkoordinasi dengan lembaga-lembaga yang kompeten di bidang cyber security selain Kominfo, yakni Badan Siber dan Sandi Negara (BSSN) yang telah dibentuk berdasarkan Peraturan Pemerintah Nomor 53 Tahun 2017 tentang Badan Siber dan Sandi Negara. Badan ini berfungsi untuk salah satunya melakukan identifikasi, deteksi, proteksi dan penanggulangan kejahatan e-commerce serta menjamin dan mengawasi sertifikasi keandalan yang dimiliki oleh pelaku usaha yang menjalankan kegiatan usahanya yang berbasis e-commerce seperti lolos standar perangkat keras, perangkat lunak, standar tenaga ahli, keamanan data, dan pengelola data.

Adanya BSSN ini jika dioptimalkan dengan baik dapat memberikan rasa aman bagi warga negara yang menjadi konsumen dalam transaksi bisnis elektronik

\footnotetext{
${ }^{31}$ Priyonggojati, A. 2019. Perlindungan Hukum Terhadap Penerima Pinjaman Dalam Penyelenggaraan Financial Technology Berbasis Peer To Peer Lending. JURNAL USM LAW REVIEW, 2(2), hlm,.162-173.

${ }^{32}$ Op.Cit. hlm. 167.
} 
Volume 16, Nomor 1, Januari - Juni 2021

karena keberadaan pelaku usaha seperti perusahaan-perusahaan fintech $P 2 P$ lending telah disertifikasi oleh Pemerintah dan diawasi oleh BSSN. Jika perusahaan tersebut ilegal, maka dapat dilakukan upaya preventif dalam mencegah perusahaan-perusahaan fintech sebelum mereka memasarkan produknya kepada konsumen. BSSN dapat melakukan verifikasi, mendeteksi server dan pusat keberadaan perusahaan-perusahaan fintech $P 2 P$ lending tersebut serta dapat dilakukan tindakan penegakan hukum lebih lanjut.

Pengawasan pemerintah dalam industri fintech sangatlah penting dan berpengaruh besar karena pengguna internet di Indonesia cukup tinggi. Tingginya angka penggunaan internet akan berdampingan dengan potensi kejahatan di sektor bisnis yang akan terjadi sehingga dibutuhkan regulasi yang mampu untuk diikut dan terkoordinasi dengan lembaga-lembaga terkait.

Konsep penegakan hukum dalam meminimalkan kegiatan perusahaan fintech $P 2 P$ lending ialah dengan cara membentuk suatu aturan yang baru diikuti dengan koordinasi pihak-pihak terkait dalam upaya preventif maupun represif agar dapat melindungi kepentingan konsumen di sektor jasa keuangan. Perkembangan industri pinjaman uang berbasis fintech tentu memerlukan kesiapan dari regulator dan pemerintah di Indonesia dalam mengaturnya, terutama yang berkaitan dengan aspek kelembagaan, kegiatan usaha, serta mitigasi risiko. ${ }^{33}$

\section{B. Peran Peer to Peer Lending dalam Menyalurkan Pendanaan pada Usaha Kecil dan Menengah}

Usaha Kecil dan Menengah memiliki jumlah pelaku pasar yang lebih besar bila dibandingkan dengan pelaku usaha golongan Besar (Non-UKM). Bilangan jumlah pelaku pasar bukanlah merupakan bilangan yang linear dengan nilai omzet yang melekat pada usaha UKM maupun usaha golongan Besar (Non-UKM).

Jumlah pemain Usaha Kecil dan Menengah ini merupakan ceruk yang dapat dilakukan penetrasi pasar oleh perusahaan FinTech khususnya Peer to Peer Lending. Sementara banyak pelaku usaha Kecil dan Menengah ini belum tersentuh fasilitas pembiayaan dari perbankan. Kedua poin kekuatan ini menciptakan suatu potensi hubungan binis yang dapat saling menguntungkan kedua belah pihak layaknya keseimbangan antara permintaan (demand) dan penawaran (supply).

\section{Usaha Kecil dan Menengah sebagai Penggerak Roda Perekonomian Indonesia}

Mengingat pada hantaman krisis moneter di Indonesia pada tahun 1998, ekonomi di Indonesia jatuh ambruk. Terlihat dari banyaknya perusahaan yang bergolongan besar banyak yang collapse disebut juga bangkrut. Salah satu faktornya disebabkan oleh pinjaman yang perusahaan tersebut terima dalam jumlah dollar

${ }^{33}$ Op.Cit. hlm. 167-168. 
sementara saat jatuh tempo pembayaran di saat hantaman krisis keuangan menjadikan nilai jual dollar sangat tinggi untuk dibeli kembali menggunakan pundi rupiah yang ada pada perusahaan. Maka dari itu banyak perusahaan besar gulung tikar baik dari ketidakmampuan dalam membayar utang dagangnya hingga menjerat kepada masalah hukum bisnis yang berlangsung kepada pihak kreditur. ${ }^{34}$ Kajian terhadap perlindungan hukum terhadap para pihak yang berkepentingan dalam financial technology-peer to peer lending dalam penelitian ini berdasarkan kepada fungsi hukum untuk melindungi kepentingan hak manusia yang telah diatur secara prosedural dalam ketentuan peraturan perundang-undangan serta memberikan perlindungan dan menjaga hak asasi manusia dimana dalam hal ini pihak investor yang telah memberikan pembiayaan sehubungan dengan adanya kepaililitan borrower dalam financial technology-peer to peer lending Dalam rangka memberikan perlindungan hukum bagi lender (kreditur), maka Undang-undang Kepalitan dan Penundaan Kewajiban Pembayaran Utang memiliki peran dalam mekanisme penyelesaian perkara seperti ini. Undang undang Kepailitan dan Penundaan Kewajiban Pembayaran Utang dinilai sebagai aturan untuk cara yang lebih cepat dan efektif dari sisi waktu penyelesaian pembayaran kembali dari borrower sebagai debitur daripada penyelesaian perkara melalui gugatan perdata biasa. Undang-undang Kepailitan memiliki perpanjangan tangan melalui Kurator atau Balai Harta Peninggalan yang memiliki kewenangan tugas untuk melaksanakan tugasnya dalam penyelesaian pembayaran kembali dari borrower sebagai debitur yang hasil pembayaran kembali nilai pinjaman tersebut yang disebut sebagai recovery.

Hal lain juga terlihat dari sisi perbankan yang mana sangat membutuhkan dalam mengimpun dana masyarakat dengan penawaran bunga hingga lebih dari $40 \%$ p.a. yang dapat dikesimpulkan bahwa kurangnya uang terhimpun yang berada pada perbankan atau dengan kata laiin banyak uang beredar di masyarakat. Hal tersebut cenderung dimiliki masyarakat untuk memputarkan keuangan untuk berusaha tanpa menafikan bahwa banyak nominal besar yang dilarikan pengusaha konglomerat untuk diparkirkan ke luar negeri yang ditransfer dari rekening bank di Indonesia.

Usaha Kecil dan Menengah di kala itu, terlihat dan dirasakan seperti tidak tersentuh badai ekonomi yang sedang melanda. Usaha Mikro Kecil dan Menengah masih tetap menjalankan aktivitas bisnis di antara antar para pelaku usaha UMKM itu sendiri maupun dengan konsumennya. Usaha Kecil dan Menengah pada masa itu seperti menggerakkan kegiatan ekonomi di saat-saat usaha besar sedang bangkrut. Hal tersebut menjadikan Usaha Mikro Kecil Menengah sebagai kegiatan ekonomi yang memicu untuk kegiatan ekonomi yang lebih besar. Sebaliknya, jika ekonomi dilakukan secara kapital belum tentu dapat menggerakkan ekonomi retail jika pasar tidak dapat menyerap nilai ekonomi yang ditawarkan oleh kegiatan usaha Non-UKM.

Usaha Kecil dan Menengah selalu menarik untuk dikaji, bukan hanya dari aspek ketahanan, aspek pembiayaan, perolehan pinjaman atau dari aspek manajerial

${ }^{34}$ Risna Kartika, Nana Darna, Iwan Setiawan,Analisis Peer to Peer Lending di Indonesia, Akuntabilitas:Jurnal Ilmu-Ilmu Ekonomi Volume 12 No.2 Tahun 2019, hlm.76. 
usaha. Pada era globalisasi khususnya dengan adanya integrasi ekonomi di Asia Tenggara, yaitu penyatuan ekonomi (Economic Union) yang menjadikan Asia Tenggara menjadi suatu komunitas perekonomian dengan basis produksi tunggal membuat UKM harus mampu mempertahankan eksistensinya ditengah gempuran ekonomi global. Dalam hal ini, UKM dituntut untuk mampu bersaing dan menciptakan produk yang dapat diterima tidak hanya oleh konsumen dalam negeri (Indonesia) tetapi juga konsumen di Asia Tenggara. ${ }^{35}$ Usaha kecil dan menengah (UKM) selalu hadir karena memang diperlukan. UKM ini selalu pula dapat membuktikan ketahanannya, terutama ketika bangsa kita dilanda badai krisis ekonomi (sejak Juli 1997). UKM ini tampak merupakan salah satu sektor usaha penyangga utama yang dapat menyerap banyak tenaga kerja. ${ }^{36}$

Perkembangan dan Pertumbuhan UKM pun cukup bagus dari tahun ke tahun. Hampir dari setiap pemerintahan menekankan pada pemberdayaan UKM. Pemerintah secara serius memberikan perhatian lebih pada sektor usaha ini. Alasannya, usaha kecil ini menjadi tulang punggung penyediaan tenaga kerja, karena perusahaan besar lebih menekankan penggunaan teknologi dari pada tenaga kerja manusia.UKM mampu menjadi stabilisator dan dinamisator perekonomian Indonesia. Sebagai negara berkembang, Indonesia sangat penting memperhatikan UKM, hal ini disebabkan UKM mempunyai kinerja lebih baik dalam tenaga kerja yang produktif, meningkatkan produktivitas tinggi, dan mampu hidup di sela-sela usaha besar. UKM mampu menopang usaha besar, seperti menyediakan bahan mentah,suku cadang, dan bahan pendukung lainnya. UKM juga mampu menjadi ujung tombak bagi usaha besar dalam menyalurkandan menjual produk dari usaha besar ke konsumen. ${ }^{37}$ Kedudukan UKM ini semakin mantap. Selain mampu menyerap tenaga kerja cukup banyak, UKM ini bersifat lincah sehingga mampu bertahan di dalam kondisi yang tidak menguntungkan, seperti terjadinya krisis global seperti saat ini. Umumnya, UKM memiliki strategi dengan membuat produk unik dan khusus sehingga tidak bersaing dengan produk dari usaha besar. ${ }^{38}$

Sejarah perekonomian telah ditinjau kembali untuk mengkaji ulang peranan usaha skala kecil dan menengah (UKM). Beberapa kesimpulan, setidak-tidaknya hipotesis telah ditarik mengenai hal ini. Pertama, pertumbuhan ekonomi yang sangat cepat sebagaimana terjadi di Jepang, telah dikaitkan dengan besaran sektor usaha kecil. Kedua, dalam penciptaan lapangan kerja di Amerika Serikat sejak perang dunia II, sumbangan UKM ternyata tak bisa diabaikan. Negara-negara berkembang yang mulai

\footnotetext{
${ }^{35}$ Miriam Segal."Peer-to-PeerLending: A Financing Alternative for Small Businesses". Jurnal. 2015, hlm. 3

${ }^{36}$ Maharani Tejasari, 2008, "Peranan Sektor Usaha dan Menengah dalam Penyerapan Tenaga Kerja dan Pertumbuhan Ekonomi Indonesia" Naskah publikasi IPB

${ }^{37}$ Benuf, K., Njatrijani, R., Priyono, E. A., \& Adhim, N. 2020. Pengaturan dan Pengaasan Bisnis Financial Technology di Indonesia. Dialogia Iuridica: Jurnal Hukum Bisnis Dan Investasi, 11(April), hlm. 46-69.

${ }^{38}$ S. Sutojo. "Menangani Kredit Bermasalah Konsep dan Kasus". Jakarta: PTDamar Mulia Pustaka.2008
} 
mengubah orientasinya ketika melihat pengalaman-pengalaman di negara-negara tentang peranan dan sumbangsih UKM dalam pertumbuhan ekonomi. Usaha kecil menengah (UKM) memainkan peran-peran penting didalam pembangunan dan pertumbuhan ekonomi, tidak hanya di Negara-negara sedang berkembang. ${ }^{39}$

Negara-negara maju, UKM sangat penting tidak hanya karena kelompok usaha tersebut menyerap paling banyak tenaga kerja dibandingkan dengan usaha besar, UKM juga berperan sangat penting khususnya dari perspektif kesempatan kerja dan sumber pendapatan bagi kelompok miskin, distribusi pendapatan dan pengurangan kemiskinan. Serta pembangunan ekonomi pedesaan.Tambunan menambahkan, dilihat dari kontribusinya terhadap Produk Domestik Bruto (PDB) dan Ekspor Non-Migas, khususnya produk-produk manufaktur, dan inovasi serta pengembangan teknologi. ${ }^{40}$

Di Indonesia, UKM juga sangat berperan sebagai roda penggerak pembangunan ekonomi. Selain itu, peran pelaku UKM dipandang sangat penting guna meningkatkan pendapatan perkapita maupun meningkatkan perekonomian suatu daerah. Pelaku UKM dituntut mampu untuk ikut serta dalam mengembangkan perekonomian negaranya terutama dalam melakukan pengembangan hal apapun guna memenuhi permintaan konsumen yang semakin spesifik, inovatif, memiliki harga yang terjangkau namun tetap berkualitas sampai dengan dapat bersaing secara global mengingat mulai memasuki masyarakat ekonomi ASEAN.Upaya pemberdayaan merupakan salah satu paradigma pembangunan yang dapat ditempuh guna mewujudkan keberhasilan pembangunan nasional. ${ }^{41}$

Salah satu upaya pemberdayaan yang dapat dilakukan yaitu melalui pemberdayaan UKM. Sektor UKM merupakan sektor usaha yang mampu bertahan pada saat krisis multidimensi tahun 1998 dan krisis global pada tahun 2008. Sampai saat ini UKM juga merupakan salah satu sektor penyumbangan terbesar nasional karenanya sektor UKM memiliki kemampuan yang dapat dimanfaatkan dan dikembangkan guna dijadikan roda perekonomian dengan tujuan agar mencapai pembangunan nasional dan regional secara efektif dan efisien. ${ }^{42}$ Peran utama UKM ialah sebagai penggerak utama roda kegiatan perekonomian Indonesia, peluang lapangan pekerjaan yang menyerap banyak tenaga kerja, pemeran penting yang menjadikan ekonomi daerah dan pengembangan masyarakat menjadi berkembang, yang menciptakan pasar menjadi berkembang dan selalu berusaha untuk berinovasi antar kegiatanperusahaan dan yang terakhir adalah sebagai pemain dalam perbaikan neraca pembayaran internasional melalui peran yang semakin nyata dalam komposisi

\footnotetext{
${ }^{39}$ Sudaryanto, Ragimun dan Rahma Rina Wijayanti, "Strategi Pemberdayaan UMKM Menghadapi Pasar Bebas Asean", dari https://www.kemenkeu.go.id

${ }^{40}$ Ade Resalawati, "Pengaruh perkembangan usaha kecil menengah terhadap pertumbuhan ekonomi pada sektor UKM Indonesia”. (skripsi Fakultas Ekonomi dan Bisnis, Universitas Islam Negeri Syarif Hidayatullah, Jakarta, 2011,hlm78.

41 Edi Suharto, Membangun Masyarakat Memberdayakan Rakyat, (Bandung: Refika Aditama 2014

${ }^{42}$ Faturocman, Kesejahteraan Masyarakat, (Yogyakarta: Pustaka Belajar, 2012)
} 
Volume 16, Nomor 1, Januari - Juni 2021

ekspor serta penghematan devisa melalui produk-produk subtitusi impor yang dikaitkan oleh UKM. ${ }^{43}$ Kontribusi UKM dalam suatu perekonomian juga dapat dilihat dari kontribusinya dalam pembentukan Produk Domestik Bruto (PDB). UKM juga memiliki peran yang cukup besar dalam ekspor dan investasi. Sehingga peluang UKM di masa mendatang dalam mengembangkan suatu produk demi menembus pasar global sangat memiliki potensi yang cukup besar dan baik dengan diiringi pengembangan produk yang lebih kreatif dan inovatif. ${ }^{44}$

UKM sangat memiliki potensi yang besar dalam bersaing namun kenyataannya UKM di Indonesia masih mengalami kesulitan dalam pembiayaan atau permodalan sehingga dari masalah tersebut sektor UKM memerlukan dukungan dari para investor. ${ }^{45}$ Melihat kondisi sektor UKM yang mampu menciptakan lapangan pekerjaan dengan penyerapan tenaga kerja yang tinggi, meningkatkan kegiatan ekpor serta penyumbang PDB terbesar maka seharusnya pemerintah mampu melakukan pemberdayaan yang berkelanjutan secara optimal guna menunjang kegiatan produksi pada sektor UKM sehingga akan berdampak pada perekonomian negara yang lebih baik. Karena sektor UKM memang masih perlu adanya pendampingan dari pemerintah guna memasukin pasar internasional sehingga tercapai tujuan negara untuk mensejahterakan masyarakat. Perlu diketahui bahwa sektor UKM mampu bersaing secara global apabila fasilitas dalam negeri memadai serta mendukungberjalannya kegiatan tersebut. ${ }^{46}$ Selain itu bukan hanya permasalahan modal saja yang masih menjadi pokok utama tetapi dalam hal pemasaran, teknologi, skillsampai sumber daya yang digunakan. Dengan melihat kontribusinya terhadap PDB sektor UKM merupakan roda penggerak prekonomian suatu negara yang memang harus dipertahankan guna memperbaiki serta meningkatkan perekonomian. Faktor-faktor yang mampu mempengaruhi pertumbuhan PDB ialah jumlah unit UKM, tenaga kerja, eskpor serta investasi.Namun di balik itu semua menurut Kementerian Koperasi dan UKM, bahwa sudah terdapat 109 unit UKM yang mengikuti sebuah acara kelas internasional yaitu pameran luar negeri yang sebelumnya para pelaku. ${ }^{47}$

UKM juga dibekali melalui pembekalan guna memiliki daya saing yang tinggi dan memiliki nilai produk yang berkualitas. Selama ini, Kementerian Koperasi dan UKM telah melakukan promosi produk di dalam dan luar negeri. Hal tersebut dilakukan dalam rangka meningkatkan akses pasar bagi produk koperasi dan usaha

43 Tulus T.H Tambunan(2002), "Usaha Kecil dan Menengah di Indonesia" Salemba Empat,hlm.33.

44 Ade Reselawati (2011), "Pengaruh Perkembangan Usaha Kecil Menengah terhadap Pertumbuhan Ekonomi pada Sektor UKM di Indonesia”. Naskah Publikasi FE UINHidayatullah Jakarta

45 Reynaldi Susanto. (2016), "Peran UKM dalam Perekonomian Indonesia", dari http://reynaldisusanto.blogspot.co.id/2016/05/peran-ukm-dalam-perekonomian-indonesia.htm

${ }^{46}$ Etty Mulyati, "Asas Keseimbangan pada Perjanjian Kredit Perbakan dengan Nasabah Pelaku Usaha Kecil”, Jurnal Bina Mulia Hukum, Vol. 1, No. 1, 2016.hlm.21.

${ }^{47}$ Tulus T.H. Tambunan, UMKM di Indonesia(Bogor : Ghalia Indonesia, 2009,hlm,,45, 
mikro, kecil, dan menengah (KUMKM).Sementara di luar negeri, UKM yang mengikuti pameran di sejumlah negara, seperti Malaysia, Hong Kong, Uni Emirat Arab, Inggris, Amerika, Tiongkok, dan Jepangtercatat sebanyak 152 UKM dan total anggaran tahun 2016 yang dikeluarkan untuk promosi diluar negeri sebanyak Rp 10,67 miliar.Dengan adanyahal tersebut harapannya sektor UKM mampu untuk terus berkontribusi dalam meningkatkan perekonomian Indonesia yang memiliki sifat keberlangsungan sehingga menciptakan perekonomian Indonesia yang semakin baik nantinya. ${ }^{48}$

\section{Peer to Peer Lending sebagai Inovasi Usaha Pendanaan Modern bagi Usaha Menengah dan Kecil}

Kegiatan ekonomi pada suatu negara biasanya ditunjang oleh sebuah lembaga intermediary atau lembaga perantara keuangan. Lembaga intermediary melakukan peran penting sebagai perantara antara masyarakat yang kelebihan dana (surplus) dengan masyarakat yang berkebutuhan dana (defisit). Kegiatannya yaitu menghimpun dana dari masyarakat yang kelebihan dana dan menyalurkannya kepada masyarakat yang kekurangan dana secara efektif dan efisien. ${ }^{49}$

Lembaga intermediary mempunyai berbagai pola dalam menjalankan perusahaanya, baik hanya menghimpun dana seperti donasi, menyalurkan dana seperti lembaga pembiayaan maupun yang menjalankan keduanya seperti Bank. Seiring dengan perkembangan teknologi, lembaga intermediary yang ada di Indonesia turut berkembang menjadi perusahaan penyedia layanan keuangan berbasis teknologi.

Usaha Kecil dan Menengah cenderung merupakan usaha yang belum bankable. Usaha yang tergolong belum bankable di sini adalah dalam arti bahwa usaha tersebut dinilai relatif belum memiliki cukup syarat untuk dapat difasilitasi oleh perbankan dalam rangka pemberian kredit modal kerja. Meskipun usaha kecil dan menengah telah memiliki dan menggunakan layanan produk perbankan lainnya seperti tabungan hingga internet banking namun tidak berarti bahwa pekaku usaha kecil dan menengah merupakan usaha yang bankable.

Persyaratan yang kerap diperlukan dalam pemberian pinjaman perbankan antara lain berupa agunan Agunan yang dimaksud tersebut sering tidak hanya sebatas tidak dimiliki oleh pengusaha UKM tersebut namun dapat berupa dokumen kepemilikannya yang tidak dapat dilakukan pengikatan hak kebendaan atas agunan. Isu yang sering nampak atas dokumen tersebut seperti alas hak yang belum merupakan yang diakui oleh negara dalam bentuk yang telah diatur dalam Undang-undang Pokok

\footnotetext{
${ }^{48}$ Mutmainah, Dinda Audriene. (2016), “Kontribusi UMKM terhadap PDB Tembus Lebih Dari 60 Persen".Diaksespada Januari 2018, dari https://www.cnnindonesia.com/ekonomi/20161121122525-92-174080/kontribusi-umkm-terhadappdb-tembus-lebih-dari-60-persen

${ }^{49}$ Titik Setyaningsih, Nugroho Wisnu Murti, Putri Nugrahaningsih, Pembiayaan Peer to Peer Lending Bagi UMKM:Mengatasi Masalah Tanpa Masalah, Jurnal IKRA-ITH Ekonomika Vol 2 No 3 Bulan Juli 2020, hlm.75.
} 
Volume 16, Nomor 1, Januari - Juni 2021

Agraria seperti berupa Sertifikat Hak Tanah; Sertifikat Hak Guna Bangunan dan lain sebagainya.

Kekuatan yang dimiliki pada pelaku saah kecil dan menengah yaitu dalam menjalankan aktivitas bisnisnya, UKM memiliki tingkat margin yang cukup tinggi daripada bila dibandingkan dengan margin yang ada pada pelaku usaha non-UKM. Margin yang maksud dapat berkisar sekitar 50\% dan bisa melebihi nilai tersebut tergantung dari jenis usaha yang berbeda-beda karakternya.

Jika melihat usaha non-UKM yang cenderung memiliki nilai kapital yang sangat besar, nilai margin yang dimiliki dapat hanya sebesar sekitar 10\% atau dapat lebih kurang daripada angka tersebut. Hal ini cenderung diebabkan oleh faktor penguasaan pasar oleh pelaku usaha besar namun dengan tingkat risiko yang berbeda dan diiringi dengan margin yang rendah.

Inovasi model perusahaan yang berupa perpaduan antara penggunaan teknologi dengan fitur layanan keuangan sering disebut fintech atau financial technology. Hingga saat ini jumlah perusahaan yang bergerak dibidang fintech sangat berkembang sebagaimana data dari Asosiasi Fintech Indonesia. ${ }^{50}$

Inovasi layanan keuangan yang telah berkembang hingga saat ini dapat memasuki masyarakat yang memiliki potensi pasar yang banyak dan tidak mampu dikuasai oleh segelintir pelaku fintech - P2P Lending. ${ }^{51}$

\section{Klasifikasi Usaha Kecil dan Menengah}

Pengertian Usaha Kecil Menengah UKM adalah jenis usaha yang paling banyak jumlahnya di Indonesia, tetapi sampai saat ini batasan mengenai usaha kecil di Indonesia masih beragam. Pengertian kecil di dalam usaha kecil bersifat relatif, sehingga perlu ada batasannya, yang dapat menimbulkan definisi-definisi usaha kecil dari beberapa segi. Menurut definisi usaha kecil dari berbagai segi tersebut adalah sebagai berikut $:^{52}$

a. Berdasarkan Total Asset

Berdasarkan total asset, pengusaha kecil adalah pengusaha yang memiliki kekayaan bersih paling banyak Rp 200.000.000,00 ( dua ratus juta rupiah) tidak termasuk tanah dan bangunan tempat membuka usaha.

b. Berdasarkan Total Penjualan Bersih Per Tahun

\footnotetext{
${ }^{50}$ Hadad, Muliaman D., Financial Technology di Indonesia, disampaikan pada acara Kuliah Umum tentang FinTech -IBS. Jakarta. 2017, hal 7.

${ }^{51}$ Pratiwi, Dita Tania, and S. B. Y. 2020. Perlindungan Hukum Terhadap Konsumen (Penerima Pinjaman) Financial Technology Yang Berbasis Peer To Peer Lending Di Indonesia. Jurnal Hukum Adigama, 3(1), hlm.472-49

52 Prayoga RR. 2015. Analisis dampak pembiayaan mikro syariah terhadap omzet usaha mikro sektor perdagangan (studi kasus KBMT Wihdatul Ummah, Kota Bogor) [Skripsi]. Bogor (ID): Institut Pertanian Bogor.
} 
Berdasarkan hal ini pengusaha kecil adalah pengusaha yang memiliki hasil total penjualan bersih per tahun paling banyak Rp 1.000.000.000 ( satu miliar rupiah).

c. Berdasarkan Status Kepemilikan

Dari segi ini, didefinisikan bahwa pengusaha kecil adalah usaha berbentuk perseorangan, bisa berbadan hukum atau tidak berbadan hukum yang didalamnya termasuk koperasi.

Berdasarkan UU No. 1 tahun 1995, usaha kecil dan menengah memiliki kriteria sebagai berikut:

1.Kekayaan bersih paling banyak Rp 200 juta tidak termasuk tanah dan bangunan tempat usaha.

2.Memiliki hasil penjualan tahunan paling banyak Rp 1 miliar.

3.Milik Warga Negara Indonesia (WNI)

4.Berdiri sendiri, bukan merupakan anak perusahaan atau cabang perusahaan yang dimiliki atau dikuasai usaha besar.

5.Bentuk usaha orang per orang, badan usaha berbadan hukum/tidak, termasuk koperasi.

6.Untuk sektor industri, memiliki total aset maksimal Rp 5 miliar.

7.Untuk sektor non industri, memiliki kekayaan bersih paling banyak Rp 600 juta (tidak termasuk tanah dan bangunan tempat usaha), atau memiliki hasil penjualan tahunan maksimal Rp 3 miliar pada usaha yang dibiayai.

Menurut BPS pada seminar di Kementerian Negara Koperasi dan UKM Tahun 2009, landasan hukum penyusunan variabel UKM 2006-2008 adalah UU No. 20 tahun 2008 tentang UKM meliputi:

1. Usaha mikro: memiliki kekayaan paling banyak Rp. 50.000.000,- atau hasil penjualan tahunan paling banyak $\mathrm{Rp} 300.000 .000$,-

2. Usaha kecil: memiliki kekayaan bersih > Rp. 50.000.000,- sampai dengan Rp 500.000.000,- atau hasil penjualan tahunan > Rp. 300.000.000,- sampai Rp.2.500.000.000,

3. Usaha menengah; memiliki kekayaan bersih > Rp.500.000.000,- sampai dengan $\mathrm{Rp} 10.000 .000$,- atau hasil penjualan > Rp 2.500.000.000,- sampai dengan $\mathrm{Rp}$ 50.000.000.000,-.

Menurut Keputusan Presiden RI no. 99 tahun 1998 Pengertian Usaha Kecil Menengah: Kegiatan ekonomi rakyat yang berskala kecil dengan bidang usaha yang secara mayoritas merupakan kegiatan usaha kecil dan perlu dilindungi untuk mencegah dari persaingan usaha yang tidak sehat. 
Menurut Badan Pusat Statistik (BPS)Pengertian Usaha Kecil Menengah: Berdasarkan kuantitas tenaga kerja. Usaha kecil merupakan entitas usaha yang memiliki jumlah tenaga kerja 5 s.d 19 orang, sedangkan usaha menengah merupakan entitias usaha yang memiliki tenaga kerja 20 s.d. 99 orang.

Berdasarkan Keputuasan Menteri Keuangan Nomor 316/KMK.016/1994 tanggal 27 Juni 1994 Pengertian Usaha Kecil Menengah: Didefinisikan sebagai perorangan atau badan usaha yang telah melakukan kegiatan usaha yang mempunyai penjualan atau omset per tahun setinggi-tingginya Rp 600.000.000 atau asset atau aktiva setinggi-tingginya Rp 600.000.000 (di luar tanah dan bangunan yang ditempati) terdiri dari:

- Bidang usaha ( Fa, CV, PT, dan koperasi )

- Perorangan ( Pengrajin/industri rumah tangga, petani, peternak, nelayan, perambah hutan, penambang, pedagang barang dan jasa)

Menurut UU No 20 Tahun 2008 Pengertian Usaha Kecil Menengah: Undang undang tersebut membagi kedalam dua pengertian yakni: Usaha Kecil adalah entitas yang memiliki kriteria sebagai berikut :

1) Kekayaan bersih lebih dari Rp 50.000.000,00 (lima puluh juta rupiah) sampai dengan paling banyak Rp 500.000.000,00 (lima ratus juta rupiah) tidak termasuk tanah dan bangunan tempat usaha.

2) Memiliki hasil penjualan tahunan lebih dari Rp 300.000.000,00 (tiga ratus juta rupiah) sampai dengan paling banyak Rp 2.500.000.000,00 (dua milyar lima ratus juta rupiah).

Sementara itu, yang disebut dengan Usaha Menengah adalah entitas usaha yang memiliki kriteria sebagai berikut :

1) Kekayaan bersih lebih dari $\operatorname{Rp} 500.000 .000,00$ (lima ratus juta rupiah) sampai dengan paling banyak Rp 10.000.000.000,00 (sepuluh milyar rupiah) tidak termasuk tanah dan bangunan tempat usaha.

2) Memiliki hasil penjualan tahunan lebih dari Rp2.500.000.000,00 (dua milyar lima ratus juta rupiah) sampai dengan paling banyak Rp 50.000.000.000,00 (lima puluh milyar rupiah).

UKM dapat diklasifikasikan menjadi 4 (empat) kelompok menurut UU No. 20 Tahun 2008 yaitu :

1. Livelihood Activities, merupakan UKM yang digunakan sebagai kesempatan kerja untuk mencari nafkah, yang lebih umum dikenal sebagai sektor informal. Contohnya adalah pedagang kaki lima.

2. Micro Enterprise, merupakan UKM yang memiliki sifat pengrajin tetapi belum memiliki sifat kewirausahaan. 
Volume 16, Nomor 1, Januari - Juni 2021

3. Small Dynamic Enterprise, merupakan UKM yang telah memiliki jiwa kewirausahaan dan mampu menerima pekerjaan subkontrak dan ekspor.4.Fast Moving Enterprise, merupakam UKM yang telah memiliki jiwa kewirausahaan dan akan melakukan transformasi menjadi Usaha Besar $(\mathrm{UB}){ }^{53}$

\section{PENUTUP}

Berdasarkan hasil penelitian tentang Peranan Peer to Peer Lending dalam Menyalurkan Pendanaan pada Usaha Kecil dan Menengah maka dapat diberikan kesimpulan bahwa permasalahan UMKM pada umumnya adalah permasalahan permodalan ini harus dapat diatasi. Oleh karena itu fintech hadir sebagai jawaban atas permasalahan yang terjadi. Melalui produk permodalannya fintech ini berusaha memberikan jawaban. Bukan hanya memberikan solusi fintech ini juga memberikan edukasi mengenai keuangan syariah sehingga literasi keuangan syariah masyarakat dapat meningkat. Pemerintah mesti mendukung program pendanaan kepada UKM yang membutuhkan pendanaan. Cara yang dapat dilakukan yaitu dengan menjadikan peerintah sebagai super lender pada perusahaan peer to peer lending. Agar pemberian kredit dapat profesional dalam penseleksiannya dan agar pemerintah dapat memberikan insentif berupa bunga yang ringan atas dana yang sedang diinvestasikannya maka pemerintah harus menjadi bagian dari Peer to Peer Lending yang berfungsi sebagai pemilik dana (lender).

\section{DAFTAR PUSTAKA}

Asnawi Haris Faulidi.2004. Transaksi Bisnis E-Commerce Perspektif Islam. Yogyakarta: Magistra Insania Press.

Adi Setiadi Saputra. 2019. Perlindungan Terhadap Pemberi Pinjaman Selaku Konsumen dan Tanggungjawab Peer to Peer Lending di Indonesia, Vol.5. No.1: Veritas Et Justitia.

Benuf, K., Njatrijani, R., Priyono, E. A., \& Adhim, N. 2020. Pengaturan dan Pengaasan Bisnis Financial Technology di Indonesia. Dialogia Iuridica: Jurnal Hukum Bisnis Dan Investasi, 11(April).

${ }^{53}$ Arief Rahmana, 2015. Usaha Kecil dan Menengah (UKM), Informasi Terdepan tentang Usaha Kecil dan Menengah (Online).http://infoukm.wordpress.com, diakses pada 13 Mei 2020 pukul 19.00. 
Volume 16, Nomor 1, Januari - Juni 2021

Baihaqi Jadzil. 2018. Financial Technology Peer-To-Peer Lending Berbasis Syariah di Indonesia. Journal of Sharia Economic Law. Institut Agama Islam Negeri Kudus. No.2.

Ernama, Budiharto dan Hendro S. 2017. Pengawasan Otoritas Jasa Keuangan Terhadap Financial Technology. Diponegoro Law Journal. No.3.

Etty Mulyati. 2016. Asas Keseimbangan pada Perjanjian Kredit Perbakan dengan Nasabah Pelaku Usaha Kecil”, Jurnal Bina Mulia Hukum, Vol. 1, No. 1.

Fry Anditya Rahayu Putri Rusadi, Kornelius Benuf, 2020, Fintech peer to peer lending as a financing alternative for the development MSMEs in Indonesia, Legallity:Jurnal Ilmiah Hukum, Vol. 8 No.2.

Faturocman, 2012. Kesejahteraan Masyarakat, Yogyakarta: Pustaka Belajar.

G.M.Fitriyadi. 2019. Analisis mitigasi resiko financial technology peer to peer (P2P) lending dalam penyaluran pembiayaan terhadap UMKM di Indonesia (Studi kasus PT. Ammana Fintek Syariah). Jurnal Ekonomi Dan Bisnis, Vol.7 No.2.

Iswi Hariyani dan Cita Yustisia Serfiyani. 2017. Perlindungan Hukum dan Penyelesaian Sengketa Bisnis Jasa PM-Tekfin, Jurnal Legislasi Indonesia Vol. 14 No. 3.

Kirana Pramesti Widya . 2018. Teknologi Finansial dan Masa Depan Pusat Perbankan. Universitas Muhammadiyah Sumatera Utara.

Kusumaatmadja Mochtar. 1986.Pembinaan Hukum Dalam Rangka Pembangunan Nasional. Bandung: Binacipta.

Kornelius Benuf, Ery Agus Priyono, Siti Mahmudah, Siti Malikhatun Badriyah, Bagus Rahmanda, A. S. 2020. Efektifitas Pengaturan dan Pengawasan Bisnis Financial Technology (Peer to Peer Lending) di Indonesia. Pandecta: Jurnal Penelitian Ilmu Hukum (Research Law Journal), Vol.15 No.2.

Kornelius Benuf. 2020. Urgensi Kebijakan Perlindungan Hukum Terhadap Konsumen Fintech Peer To Peer Lending Akibat Penyebaran Covid-19. Jurnal Rechts Vinding: Media Pembinaan Hukum Nasional, Vol.9 No. 2.

Leng Song Yee. 2018. Financial Technologies : A Note on Mobile Payment, Jurnal dan Perbankan. No. 2.

Noor, T. C. 2020. Aspek Hukum Pemanfaatan Digital Signature Dalam Meningkatkan Efisiensi, Akses Dan Kualitas Fintech Syariah. Jurnal Rechts Vinding: Media Pembinaan Hukum Nasional, Vol. 9 No. 2.

Nuzul Rahmayani, Tinjauan Hukum Perlindungan Konsumen Terkait Pengawasan Perusahaan Berbasis Financial Technology di Indonesia, Pagaruyuang Law Journal Volume 2 No.1, Juli 2018. 
Volume 16, Nomor 1, Januari - Juni 2021

Priyonggojati, A. 2019. Perlindungan Hukum Terhadap Penerima Pinjaman Dalam Penyelenggaraan Financial Technology Berbasis Peer To Peer Lending. JURNAL USM LAW REVIEW, Vol. 2 No.2.

Pratiwi, Dita Tania, and S. B. Y. 2020. Perlindungan Hukum Terhadap Konsumen (Penerima Pinjaman) Financial Technology Yang Berbasis Peer To Peer Lending Di Indonesia. Jurnal Hukum Adigama, Vol. 3 No.1.

Resalawati Ade.2011. "Pengaruh perkembangan usaha kecil menengah terhadap pertumbuhan ekonomi pada sektor UKM Indonesia". Skripsi Fakultas Ekonomi dan Bisnis, Universitas Islam Negeri Syarif Hidayatullah, Jakarta.

Risna Kartika, Nana Darna, Iwan Setiawan. 2019. Analisis Peer to Peer Lending di Indonesia, Akuntabilitas:Jurnal Ilmu-Ilmu Ekonomi Volume 12 No.2.

Reynaldi Susanto. 2016, "Peran UKM dalam Perekonomian Indonesia", dari http://reynaldisusanto.blogspot.co.id/2016/05/peran-ukm-dalam-perekonomianindonesia.htm

Ratna Hartanto dan Juliyani Purnama Ramli, 2018, Hubungan Hukum Para Pihak dalam Peer to Peer Lending, JH Ius Quia Iustum Volume 25 No. 2, Mei.

Setiawan Heri, Mutiara Girindra, dan Octavianna Evangelista. 2017. Aspek hukum finansial teknologi di indonesia: regulasi startup fintech oleh bank indoneisa dalam pelarangan perkembangan penggunaan bitcoin di indonesia.

Suharto Edi,2014. Membangun Masyarakat Memberdayakan Rakyat, Bandung: Refika Aditama

Suharyati dan Pahrizal Sofyan.2018. Edukasi Fintech Bagi Masyarakat Desa Bojong Sempu Bogor. Jurnal Bakti Masyarakat Indonesia. Jakarta: Universitas Pembangunan Nasional Veteran. No. 2.

Sidabalok Janus. 2012.Hukum Perusahaan: Analisis Terhadap Pengaturan Peran Perusahaan Dalam Pembangunan Ekonomi Nasional Di Indonesia. Bandung: Nuansa Aulia.

Soekanto Soerjono. 1983. Faktor-Faktor Yang Mempengaruhi Penegakan Hukum. Jakarta: Rajawali Press.

Segal Miriam .2015."Peer-to-PeerLending: A Financing Alternative for Small Businesses". Jurnal.

S. Sutojo. 2008. Menangani Kredit Bermasalah Konsep dan Kasus”. Jakarta: PT Damar Mulia Pustaka.

Sudaryanto, Ragimun dan Rahma Rina Wijayanti, "Strategi Pemberdayaan UMKM Menghadapi Pasar Bebas Asean”, dari https://www.kemenkeu.go.id 
Volume 16, Nomor 1, Januari - Juni 2021

Titik Setyaningsih, Nugroho Wisnu Murti, Putri Nugrahaningsih, Pembiayaan Peer to Peer Lending Bagi UMKM:Mengatasi Masalah Tanpa Masalah, Jurnal IKRA-ITH Ekonomika Vol 2 No 3 Bulan Juli 2020.

Tejasari Maharani, 2008, "Peranan Sektor Usaha dan Menengah dalam Penyerapan Tenaga Kerja dan Pertumbuhan Ekonomi Indonesia" Naskah publikasi IPB

Tsuroyya Dhiya dan Muzayyanah. 2019. Analisis Pelaksanaan Musyarakah Pada Layanan Financial Technology Peer To Peer Lending Syariah Di Indonesia (Studi Pt Syarfi TeknologiFinansial) No.2.

Tambunan Tulus T.H .2002. Usaha Kecil dan Menengah di Indonesia,Salemba Empat.

Vincent Fabian Thomas. OJK Akui Terhambat Payung Hukum Soal Penanganan P2P Lending Ilegal.https://tirto.id/ojk-akui-terhambat-payung-hukum-soal-penangananp2p-lending-ilegal-diUu.. diakses tanggal 14 Desember 2020.

Wijaya Reynold. P2P Lending: Wujud Baru Inklusi Keuangan. diakses tanggal 14 Desember 2020

Wahid Wachyu Adi Winarto. 2020. Peran Fintech dalam Usaha Mikro Kecil dan Menengah (UMKM). Jurnal Ekonomi \& Ekonomi Syariah, Vol.3 No.1. 